\title{
ZAKAT SERIKAT USAHA DALAM \\ PERSPEKTIF EKONOMI ISLAM
}

\author{
Husin Bafadhal \\ Pegawai Kantor Urusan Agama Sungai Bahar \\ husinbafadhal.usman@gmail.com
}

\begin{abstract}
Abstrak
Temuan penelitian ini ialah menyatakan bahwa harta yang terdapat dalam serikat usaha wajib dikeluarkan zakatnya bila telah memenuhi ketentuan nisab dan haul dalam pelaksanaan zakat, zakat tersebut atas nama pemilik harta yang berserikat, bukan atas nama serikat usaha. Adapun rincian kesimpulan ialah 1. Hukum zakat harta serikat usaha adalah wajib. Meskipun masih terdapat perbedaan pendapat para fuqaha dalam menentukan nisab dan haul zakat harta serikat usaha tersebut. Perbedaan ini didasarkan pada pemahaman mereka terhadap hukum zakat harta serikat usaha sebagaimana yang telah ditetapkan secara jelas dan tegas dalam alQur'an dan Sunnah. 2. Para fuqaha berbeda pendapat tentang ketentuan nisab zakat serikat usaha. Perbedaan tersebut adalah antara yang berpandangan bahwa nisab dan haul dilihat dari serikat usaha dan yang berpandangan bahwa perhitungan nisab atas harta masing-masing peserta serikat usaha, bukan pada serikat usaha. 3 . Ketentuan kadar wajib zakat atas harta serikat usaha disesuaikan dengan jenis usaha yang dilakukan. 4. Pelaksanaan zakat serikat usaha disesuaikan dengan bidang usaha yang dilakukan oleh serikat usaha, menurut pandangan ulama Hanafiyah: nisab yang dihitung adalah nisab dari masing-masing individu peserta serikat usaha, bukan pada serikat usahanya sendiri, oleh karenanya dalam suatu serikat usaha boleh jadi salah seorang atau beberapa orang pesertanya tidak terkena wajib zakat karena tidak mencapai nisab secara individu. Menurut pandangan ulama Syafi'iyah: nisab yang dihitung adalah nisab pada serikat usaha, apabila serikat tersebut telah mencapai nisab maka atas masing-masing individu peserta serikat usaha dikenakan wajib zakat.
\end{abstract}

Kata Kunci: Zakat, Serikat Usaha, Ekonomi Islam.

\section{PENDAHULUAN}

Islam sebagai pandangan hidup (way of life) umat merupakan ajaran yang tidak hanya bersifat dokmatis, tetapi juga bersifat praktis. Sumber utama ajaran Islam adalah al-Qur'an dan al-Sunnah, sedangkan sumber praktisnya adalah 
sosok pribadi Rasulullah SAW, para Sahabat, Tabi'in dan ulama yang mewarisinya ${ }^{1}$. Dengan demikian, segala ajarannya dapat dipahami oleh manusia, baik secara tekstual maupun kontekstual.

Sebagai seorang praktisi, Rasulullah SAW tidak hanya membawa ajaran baru yang merombak segala tradisi masyarakat jahiliyah yang menyimpang dari aturan Ilahi dan norma kemanusiaan saat itu, tetapi juga menyempurnakan dan menyelesaikan segala permasalahan yang muncul. Dalam menyikapi persoalan yang dihadapkan kepadanya, Rasulullah SAW berupaya merujuknya kepada wahyu, ketika tidak ditemukan kasus tersebut berdasarkan wahyu maka ia berusaha maksimal untuk melakukan upaya ijtihad sejalan dengan prinsip wahyu. Agaknya metoda kerja Rasul tersebut yang juga ditiru oleh Mu'az ibn Jabal ketika diutus menjadi qadhi di Yaman. ${ }^{2}$

Petunjuk wahyu lebih dominan memberikan penjelasan terhadap persoalan yang berkaitan dengan bidang akidah dan ibadah, sedangkan terhadap persoalan-persoalan hukum hanya sedikit dan bersifat global. ${ }^{3}$

Salah satu bentuk ibadah yang dimaksud adalah ibadah zakat, yang merupakan rukun Islam yang wajib dibayarkan oleh setiap muslim dan muslimat yang telah memenuhi persyaratan, baik syarat-syarat yang berkaitan dengan orang yang wajib berzakat, penerima zakat, jenis harta yang dizakatkan, maupun syarat sahnya zakat.

1Para ulama berbeda pendapat dalam hal sumber praktis selain pada diri Nabi. mereka yang tidak menerima amal Abl al-Madinah sebagai sumber, maka secara otomatis hanya mengakui al-Quran, hadits, dan praktik nabi, sementara bagi yang memasukkan amal Ahl al-Madinah sebagai rujukan ijtihad mereka, maka berarti juga mengakui praktik para sahabat dan tabi'in sebagai sumber hukum.

${ }^{2}$ Ketika akan diutus ke Yaman, Nabi SAW. bertanya kepada Mu'az: dengan cara apa engkau menyelesaikan suatu perkara? Mu'az menjawab: Aku putuskan sesuai dengan yang terdapat dalam Kitab Allahlm. Jika tidak kau temukan padanya? Tanya Nabi. Mu'az kembali menjawab: Aku putuskan sejalan dengan Sunnah Rasulullahlm. Apabila juga tidak engkau temukan padanya? Tanya Nabi kembali. Aku melakukan upaya ijtihad, Jawab Mu'az. Mendengar

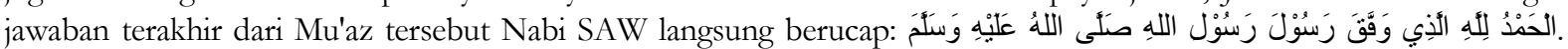
Lihat: Mausu'ah al-Hadits al-Syarif, Sunan al-Turmudzi, Kitab: al-Ahkam 'an Rasulillah, Bab: Ma Ja'a fi al-Qadhi kaifa Yaqdhi, hadits nomor: 1249.

3Ahmad Syalaby merinci terdapat 330 ayat al-Qur'an yang berbicara mengenai hukum mencakup berbagai aspek antara lain: mengenai ibadah berjumlah 140 ayat, mengenai urusan keluarga (nikah, thalak, warisan, wasiat, dan penghentian hak untuk sementara waktu) berjumlah 70 ayat, mengenai persoalan jual-beli, gadai, sewa menyewa, perkongsian, perniagaan dan hutang piutang berjumlah 70 ayat, mengenai hukuman dan pidana berjumlah 30 ayat, dan mengenai qadha dan kesaksian berjumlah 20 ayat. Lihat : Ahmad Syalaby, Tarikh at-Tasyri' al-Islamy, (Kairo: Maktabah al-Nahdhah al-Misriyyah, tt), hlm. 20-22. 
Salah satu syarat dalam zakat adalah syarat yang berkaitan dengan harta yang akan dizakatkan yaitu: milik penuh, berkembang, cukup senisab, adanya haul, lebih dari kebutuhan pokok, dan bebas dari hutang, karena harta mempunyai kedudukan yang tinggi dan nilai-nilai yang strategis dalam kehidupan manusia, karena ia merupakan alat dan sarana untuk memperoleh berbagai manfaat dan mencapai kesejahteraan hidup manusia sepanjang waktu. ${ }^{4}$ Manusia harus berusaha mendapatkannya dengan mengelola seluruh isi bumi dan mengadakan penelitian untuk mencari sumber kekayaan alam tersebut.

Melihat betapa pentingnya urgensi dan kedudukan harta bagi kehidupan manusia, maka al-Qur'an mengangkat terma harta tersebut dengan berbagai derivasinya sebanyak 86 kali, tersebar dalam 38 surah. Di samping itu, terhadap pencarian harta benda itu al-Qur'an dan Hadis sendiri memberikan legitimasi, diantaranya Allah SWT menyatakan bahwa bumi ini diciptakanNya untuk kemudahan bagi manusia, karenanya berlayarlah ke seluruh penjuru bumi dan makanlah sebagian dari rezeki-Nya, ${ }^{5}$ hanya saja Ia mengingatkan bahwa seluruh manusia akan kembali keharibaannya untuk mempertanggung jawabkan seluruh perbuatannya selama di dunia ini. Pada bagian lain Allah SWT memerintah manusia untuk mencari rezekinya di muka bumi ini setelah mereka melaksanakan kewajiban (shalat). ${ }^{6}$

Dalam Islam, harta tidak hanya dipergunakan untuk kepentingan individu semata, tapi juga untuk kepentingan sosial. Kepentingan individu adalah untuk memenuhi kebutuhan hidup yang bersangkutan dan keluarganya, tabungan hari tua serta untuk memenuhi kebutuhan spiritual dalam menjalankan kewajiban ibadah kepada Allah SWT seperti berzakat, berhaji, dan ibadah-ibadah lainnya yang membutuhkan harta benda. Sedang kepentingan sosial adalah untuk

${ }^{4}$ Abi Ubaid Qasim bin Salam, Kitab al-Amwal, (Kairo: Dar al-Fikr, 1975), hlm. 17

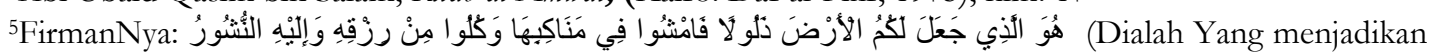
bumi itu mudah bagi kamu, maka berjalanlah di segala penjurunya dan makanlah sebahagian dari rezki-Nya. Dan hanya kepada-Nya-lah kamu (kembali setelah) dibangkitkan).

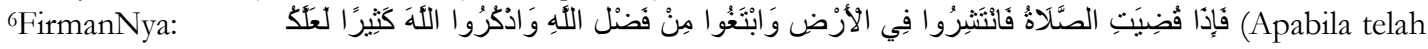
ditunaikan sembahyang, maka bertebaranlah kamu di muka bumi; dan carilah karunia Allah dan ingatlah Allah banyak-banyak supaya kamu beruntung). 
memenuhi kewajiban sosial, seperti memberikan infak, shadaqah, dan sumbangan sosial lainnya. ${ }^{7}$

Pada dasarnya harta memang menunjang kehidupan manusia, dan agar manusia tidak terjerumus dengan kemegahan harta, Islam mengajarkan kepada umat manusia bahwa Allah SWT pemilik mutlak segala sesuatu yang ada di muka bumi ini, termasuk harta benda. Kepemilikan oleh manusia hanya bersifat relatif, sebatas untuk melaksanakan amanah. ${ }^{8}$

Zakat adalah ibadah maliyah ijtima'iyah yang memiliki posisi yang sangat penting, strategis dan menentukan. Zakat juga termasuk salah satu sendi pokok ajaran Islam,' bahkan zakat dan shalat dijadikan oleh al-Qur'an dan Hadis sebagai lambang dari keseluruhan ajaran Islam. ${ }^{10}$ Zakat ditinjau dari segi bahasa (etimologi), kata zakat merupakan kata dasar (masdar) dari kata zakâ ( ) mengandung arti berkah, tumbuh, bertambah, bersih, dan baik. Sehingga dapat dikatakan bahwa rangkuman arti dari frasa zakat adalah suci (الطهارة), tumbuh ( ), berkah ( ) , dan terpuji ( $\quad) \cdot{ }^{11}$ Sedangkan secara terminologi berarti sejumlah harta tertentu yang diwajibkan oleh Allah SWT diserahkan kepada orang-orang yang berhak menerimanya. ${ }^{12}$

Di samping itu, jika dilihat dari sisi pembangunan kesejahteraan, zakat juga merupakan salah satu instrumen pemerataan pendapatan. Dengan zakat yang dikelola dengan baik, dimungkinkan membangun pertumbuhan ekonomi sekaligus pemerataan pendapatan (economy growth with equity). ${ }^{13}$ Zakat merupakan sumber utama kas negara sekaligus soko guru dari kehidupan ekonomi yang dicanangkan

\footnotetext{
${ }^{7}$ Lihat Ramlie Djalil, Peranan ZIS Dalam Pemberdayaan Ekonomi Umat, Makalah disampaikan pada Seminar Lokakarya Manajemen BAZIS tanggal 11 Agustus 1998, (Jambi: BAPPEDA Tingkat I, 1998), hlm. 3. hlm. 42.

${ }^{8}$ Muhammad Syafi'i Antonio, Bank Syariah Wacana Ulama \& Cendikiawan, (Jakarta: Bank Indonesia, 1999),

${ }^{9}$ Zakat merupakan rukun Islam yang ketiga sebagaimana Hadits dari Ibn Umar, Rasulullah SAW

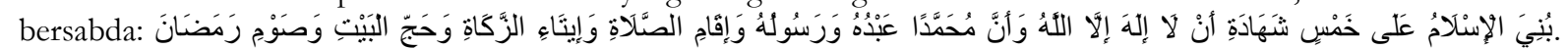
Lihat: Mausu'ah al-Hadits al-Syarif, Shahih Muslim, Kitab: al-Iman, Bab: Bayan Arkan al-Islam wa Da'a'imih al-'Izham, hadits nomor: 21.

${ }^{10}$ Ismail Muhammad Syah, Filsafat Hukum Islam, (Jakarta: Bumi Aksara, 1992), hlm. 187.

${ }^{11}$ Lihat: Muhammad ibn Makram ibn Manzur al-Afriqi al-Mishri, Lisan al-Arab, (Beirut: Dar al-Shadir), Cet I, Jilid XIV, hlm. 358. selanjutnya disebut ibn Manzur Lisan al-Arab.

${ }^{12}$ Yusuf al-Qardawi, Figh al-Zakah, (Mesir: Dar al-Fikr, 1997), hlm. 37-38.

${ }^{13}$ Ahmad Muflih Saefuddin, Pengelolaan Zakat ditinjau dari Aspek Ekonomi, (Bontang: Badan Dakwah Islamiyah LNG, 1986), hlm. 99.
} 
al-Qur'an. Zakat akan mencegah terjadinya akumulasi harta pada satu orang, dan pada saat yang sama mendorong manusia untuk melakukan investasi dan mempromosikan distribusi. ${ }^{14}$

Secara tegas Allah SWT melarang terjadinya akumulasi harta di tangan seseorang atau sekelompok orang kaya saja, sebagaimana firman-Nya:

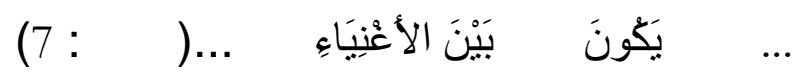

“... Agar harta itu jangan hanya beredar di antara orang-orang kaya saja di antara kamu ..."15

Dewasa ini masyarakat ekonomi menengah ke atas tidak hanya bergelut dengan satu bidang usaha, umumnya di samping mereka memegang langsung suatu usaha pribadi, mereka juga ikut ambil bagian dalam kerjasama (serikat usaha) pada institusi ekonomi yang dikelola secara profesional, baik sebagai pengurus maupun hanya sebagai anggota biasa (penanam saham), atau, jika tidak, uang hasil usaha pribadi tersebut mereka amankan dan sekaligus bekerja di institusi perbankan ${ }^{16}$ yang mereka percaya.

Serikat usaha merupakan kata majemuk yang terdiri dari kata serikat dan usaha. Serikat adalah sekumpulan orang yang merupakan kesatuan untuk mengerjakan sesuatu. ${ }^{17}$ Sedangkan usaha adalah kegiatan dengan mengerahkan tenaga, pikiran dan badan untuk mencapai suatu maksud. Atau pekerjaan (perbuatan, prakarsa, ikhtiar, daya upaya) untuk mencapai sesuatu. ${ }^{18}$ Sedangkan serikat usaha adalah suatu bentuk kegiatan bersama dalam bidang ekonomi (usaha) yang dilakukan oleh sekumpulan orang yang merupakan kesatuan untuk mengerjakan sesuatu, dengan tujuan untuk mencapai suatu maksud, atau pekerjaan. ${ }^{19}$ Kata serikat usaha dalam kitab fiqh dinyatakan sebagai salah satu bentuk kegiatan usaha secara bersama-sama yang dikenal adalah syirkah ( )

${ }^{14}$ Mustaq Ahmad, Etika Bisnis Dalam Islam, Terjemahan Samson Rahman, Jakarta: Pustaka Al-Kautsar, 2001), hlm. 75 .

${ }^{15}$ Anonim, al-Qur'an dan Terjemahnya. (Jakarta; Yayasan Penterjemah al-Qur'an, 1985), hlm. 916.

${ }^{16}$ Sebagai nasabah, mereka dinilai sebagai penanam saham yang akan memperoleh bunga (Bank konvensional) atau hasil mudharabah (Bank Syari'ah) yang ketentuan persentase bunga dan hasil mudharabah sesuai dengan ketentuan pada masing-masing Bank yang bersangkutan.

${ }^{17}$ Anonim, Kamus Besar Bahasa Indonesia, (Jakarta: Balai Pustaka, 1990), hlm. 63.

${ }^{18} \mathrm{Ibid}$, hlm. 997.

${ }^{19} \mathrm{Ibid}$. 
atau serikat ( ), anggota syirkah disebut dengan syarik ( ), bentuk jamaknya syuraka' ( ).

Kerjasama atau serikat usaha, di dalam kitab-kitab fikih dinyatakan sebagai menjalin hubungan kerjasama antara dua orang atau lebih. ${ }^{20}$ Kerjasama tersebut secara sederhana biasanya dilakukan oleh dua orang atau lebih yang saling kenal dan saling percaya dengan aturan kesepakatan yang disetujui oleh masing-masing pihak. Kerjasama dalam bentuk ini dapat dikatakan sebagai kerjasama usaha antar individu.

Dalam skala menengah, ialah kerjasama usaha yang para anggotanya terbatas pada kelompok tertentu, seperti kelompok warga, kelompok pada unit kerja, kelompok kesamaan aliran dan partai atau kelompok-kelompok lainnya. Mereka yang tergabung dalam salah satu kelompok ini, dapat membentuk suatu kerjasama usaha yang biasanya dalam bentuk koperasi.

Sementara dalam skala yang lebih besar, biasanya memiliki aturan tertulis yang transparan, yang melibatkan jumlah orang yang jauh lebih banyak, pada suatu lembaga, dan dibentuk untuk menyatukan faktor-faktor produksi, seperti: tenaga kerja, material, dana, barang-barang dan jasa, dengan tujuan untuk memperoleh laba (keuntungan). Serikat usaha dalam bentuk skala besar ini berbeda dengan serikat menengah dan sederhana. Perbedaan ini terutama terletak pada aspek motivasi, sistem lembaga dan penggunaan faktor-faktor ekonominya. Serikat dalam skala besar ini tidak mengharuskan setiap individunya saling mengenal seperti pada skala sederhana ataupun dari kelompok yang sama seperti pada skala menengah. Meskipun demikian mereka dapat menyatu dengan baik karena peraturan dan sistem yang diterapkan secara profesional.

Serikat usaha dalam skala besar di Indonesia umumnya berbentuk Badan Usaha Milik Negara (BUMN), dan Badan Usaha Milik Swasta (BUMS), yang

${ }^{20}$ Ibrahim ibn Ali ibn Yusuf al-Syirazi, al-Muhadzdzab fi Fiqh al-Imam al-Syafi'i, (Beirut: Dar al-Fikr, t.thlm.), juz I, hlm. 150. 
terdiri dari; Perseroan Terbatas (PT), Persekutuan Komanditer (CV), Persekutuan Firma, Perusahaan Internasional (Asing).

Dalam kitab-kitab fikih bentuk-bentuk kerjasama (al-musyarakah) dalam upaya membangun perekonomian pada umumnya lebih dikenal dengan istilah; almudharabah, syirkah al-Inan, al-mufawadhah, al-abdan, al-wujuh, al-muzara'ah (almukhabarah), al-musaqat dan al-mugharasah. Bentuk-bentuk kerjasama dalam operasionalnya mirip sekali dengan serikat usaha yang ada di Indonesia saat ini.

Jika diperhatikan dari hasil yang diperoleh dari serikat usaha tersebut, sudah memenuhi ketentuan wajib zakat, baik dari sisi: nisab, haul dan kadar wajib zakat, dengan tidak memperhatikan kemampuan pemilik harta tersebut, karena harta mereka telah tergabung dalam serikat usaha. Berdasarkan faktor penilaian keekonomian, seluruh anggota yang berada dalam serikat usaha skala menengah dan besar adalah mereka yang telah terkena aturan wajib zakat yang biasanya mereka mengeluarkan zakatnya secara individual.

Dengan demikian, apakah harta hasil serikat usaha dikeluarkan zakatnya atas nama serikat usaha dan para pemilik saham menerima sisa hasil usaha (SHU) yang telah dizakatkan, atau sisa hasil usaha tersebut langsung diberikan kepada para pemilik saham sebelum dikeluarkan zakatnya dan zakat tersebut, seperti yang berlaku selama ini, merupakan urusan para pemilik saham secara individu. Jika zakat dikeluarkan melalui serikat usaha, akan muncul masalah tentang ketentuan nisab dan kadar wajib zakat yang harus dikeluarkan, sebab serikat usaha tersebut terdiri dari dua orang atau lebih. Pemberlakuan kewajiban zakat atas segala bentuk usaha tersebut, menyangkut siapa diantara anggota serikat tersebut yang memikul kewajiban zakat dan penentuan nisab dan kadar kewajibannya. Bentuk-Bentuk Serikat usaha

\section{TINJAUAN UMUM TENTANG SERIKAT USAHA}

Dalam sistem mu'amalah Islam, bentuk-bentuk kegiatan usaha secara bersama-sama yang dikenal adalah syirkah ( ) atau serikat ( ), sedangkan anggota syirkah disebut dengan syarik ( ), bentuk jamaknya syuraka' ( ). 
Adapun pengertian syirkah secara etimologi (bahasa), kata syirkah merupakan kata dasar (masdar) dari kata syaraka ( ), yang berarti berserikat. ${ }^{21}$ Sedangkan menurut istilah: Syirkah adalah suatu akad kerjasama antara dua pihak atau lebih dalam pelaksanaan sebuah usaha, dimana masing-masing pihak memberikan kontribusi modal usaha atau jasa (keahlian), dan berdasarkan kesepakatan bersama, maka keuntungan serta resiko sama-sama ditanggung.

Berdasarkan pengertian di atas jelaslah bahwa Syirkah adalah suatu akad kerja sama antara dua pihak atau lebih dalam pelaksanaan sebuah usaha, dimana masing-masing pihak memberikan kontribusi modal usaha atau jasa (keahlian), berdasarkan kesepakatan bersama dan keuntungan serta resiko ditanggung bersama sesuai yang telah disepakati keduanya.

Rukun dalam syirkah secara umum adalah:

1. Shighat (ijab dan qabul)

2. Pihak yang melakukan transaksi (shabibul mal dan rabbul mal) ${ }^{22}$, dan pelaksana (musyarik)

3. Objek akad (proyek/usaha). ${ }^{23}$

Sedangkan syarat-syarat umum dalam syirkah adalah:

1. Usaha tersebut dalam pelaksanaan transaksi dapat diwakilkan

2. Pembagian keuntungan bagi setiap anggota dijelaskan nisbah (persentase) ketika terlaksananya akad.

3. Keuntungan dari usaha tersebut dibagi berdasarkan laba (hasil usaha) dari usaha bersama, dan tidak dari harta yang lain. ${ }^{24}$

Pada dasarnya ulama fikih membagi syirkah dalam 2 bentuk, yaitu:

1.Syirkah al-Amlak (perserikatan dalam kepemilikan)

${ }^{21}$ Lihat: Muhammad ibn Makram ibn Manzur al-Afriqi al-Mishri, Lisan al-Arab, op cit, hlm. 358.

${ }^{22}$ Shabibul mal adalah pemilik harta (modal) dan rabbul mal adalah orang yang mengelola harta (modal) tersebut/nazir. Kedua peristilahan ini dipakai oleh Imam al-Syafi'im khususnya pada pembahasan tentang zakat. Lihat: Muhammad ibn Idris al-Syafi'i, al-Umm, (Beirut: Dar al-Fikr, 1983/1393), Juz II, hlm. 38.

${ }^{23}$ Sayyid Sabiq, Fiqh al-Sunnah, Juz III, op cit, hlm. 294.

${ }^{24}$ Ibid, hlm. 295. 
Syirkah al-Amlak ialah peralihan kepemilikan harta kepada dua orang atau lebih tanpa harus ada akad. Syirkah seperti ini dapat terjadi dalam bentuk Ikhtiyariyah dan bentuk Ijbariyah. ${ }^{25}$

a. Syirkah al-Amlak Ikhtiyariyah

Syirkah al-Amlak Ikhtiyariyah ialah Peralihan kepemilikan dalam bentuk Ikhtiyariyah yang terjadi apabila seorang pemilik harta melakukan hibah sebagian hartanya kepada dua orang dan keduanya menerima hibah tersebut, atau seseorang berwasiat atas sebagian hartanya untuk dua orang dan kedua orang tersebut menerima wasiat tersebut.

b. Syirkah al-Amlak Ijbariyah

Syirkah al-Amlak Ijbariyah ialah kepemilikan harta dalam bentuk Ijbariyah, yaitu peralihan kepemilikan harta karena waris. Harta yang dimiliki oleh seseorang yang meninggal dunia tersebut secara otomatis beralih menjadi milik ahli warisnya sesuai dengan aturan kewarisan yang berlaku. ${ }^{26}$

2.Syirkah al-Uqud (perserikatan dalam akad/serikat usaha)

Syirkah al-uqud tercipta disebabkan adanya kontrak (akad) dan ini juga dikenal dengan istilah syirkah ikhtiyariyah (pilihan) atau serikat usaha terjadi dengan cara adanya kesepakatan antara dua orang atau lebih telah menyetujui bahwa setiap anggota ikut akan memberikan modal usaha serikat usaha tersebut, sebagaimana yang akan dikemukan berikut ini:

a. Mudharabah (Kerjasama Bagi Hasil)

Secara terminologi mudharabah adalah :

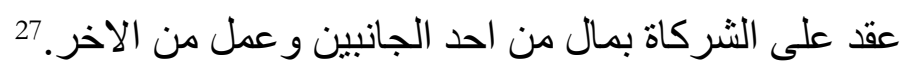

"Kesepakatan kerjasama antara dua pihak, satu pihak sebagai penyandang dana permodalan dan pihak lain sebagai pelaksana".

${ }^{25}$ Ibid, hlm. 296.

${ }^{26}$ Ibid.

${ }^{27}$ Ibid. 
b. Syirkah al-Inan

Menurut Wahbah al-Zuhaili bahwa syirkah al-Inan adalah :

أن يشترك إثنان فى مال لهما على أن يتجر ا فيه والربح بينهما ولا يشترط فيها المساواة فى

28 .

"Syirkah al-Inan adalah dua orang yang berserikat pada harta milik keduanya untuk diperdagangkan berdua dan keuntungan milik berdua, tidak diisyaratkan "persamaan pada harta, juga tidak pada wewenang dan keuntungan ".

c. Syirkah al-Abdan

Menurut Abi Ishak al-Syirazi bahwa syirkah al-abdan adalah:

$$
\text { و أما شركة الأبدان وهي الثركة على ما يكتسبان بأبدانهما.29 }
$$

"Syirkah al-Abdan adalah syirkah terhadap sesuatu antara pihak-pihak yang berserikat sama berusaha atau sama bekerja dengan anggota tubuh atau tangannya ".

\section{d. Syirkah al-Mufawadhah}

Menurut Sayyid Sabiq bahwa syirkah al-mufawadhah adalah:

$$
\begin{aligned}
& \text { التعاقد بين الإثنين أو أكثر على الإشتر الك فى عمل بالثروط الآبية: } \\
& \text { 3. التساوى فى الدين } \\
& \text { 4. أن يكون كل واحد من الثركاء كفيلا عن الآخر. } 30
\end{aligned}
$$

"Syirkah al-Mufawadhah adalah akad kesepakatan antara dua orang atau lebih untuk berserikat dalam usaha permodalan dengan syarat sebagai berikut: (1) Harus sama dalam modal, (2) Harus sama dalam kewenangan pengelolaan, (3) Harus sama dalam hutang, (4) Harus sama dalam perwakilan satu sama lainnya ".

e.Syirkah al-Wujub

Menurut Wahbah al-Zuhaili bahwa syirkah al-wujub adalah:

${ }^{28}$ Sayyid Sabiq, ibid, hlm. 295-296.

${ }^{29}$ Ibrahim ibn Ali ibn Yusuf al-Syirazi, Abu Ishaq, al-Muhadzdzab fi Figh al-Imam al-Syafi'i, (Beirut: Dar alFikr), t.thlm., juz I, hlm. 346.

${ }^{30}$ Ibid, hlm. 296. 


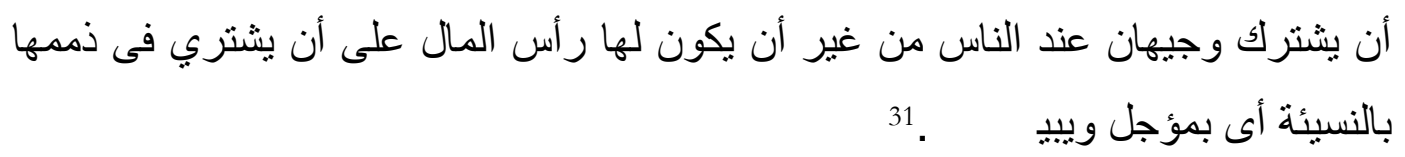

"Syirkah al-Wujuh adalah serikat yang dilakukan dua orang atau lebih, yang keduanya tidak memiliki modal tunai, dan mereka membeli suatu barang dengan kredit dan menjual kembali barang tersebut secara tunai".

f. al-Murara'ah

Imam al-Syafi'i mendefenisikan al-muzara'ah adalah:

$$
\text { عمل العامل في الأرض ببعض ما يخرج منها والبذر من العامل.32 }
$$

"Pengolahan tanah oleh petani dengan imbalan hasil pertanian, sedangkan bibit pertanian disediakan oleh penggarap tanah"

g. al-Mukhabarah

Secara terminologi sama artinya dengan istilah dalam al-muzara'ah, hanya saja penduduk Irak biasa menyebutnya dengan istilah "almukhabarab" yang berarti juga sama dengan al-muzara'ah. Adapun rukun dan syarat-syarat dalam al-mukhabarah sama dengan yang terdapat dalam rukun dan syarat-syarat dalam al-muzara'ah. ${ }^{33}$ Perbedaan antara al-muzara'ah dengan al-mukhabarah adalah terdapat pada penyediaan bibit pertanian tersebut, jika bibit pertaniannya disediakan oleh pemilik tanah disebut dengan al-muzara'ah, dan sebaliknya jika bibit pertaniannya disediakan oleh petani penggarap disebut al-mukhabarah.

h. Al-Musaqah

Menurut ulama fikih adalah:

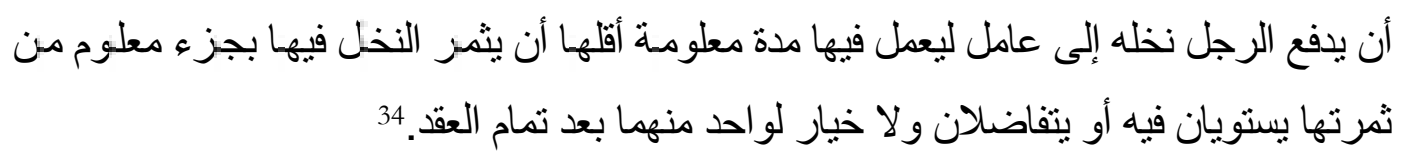

"Penyerahan sebidang tanah kebun kepada seorang petani untuk digarap dan dirawat dalam waktu yang disepakati, minimal sekali panen, dengan ketentuan bahwa masing-masing pihak mendapat bagian yang sama atau

${ }^{31}$ Wahbah al-Zuhaili, Fiqh al-Islami, ibid, hlm. 799.

${ }^{32}$ Al-Syarbaini al-Khatib, Mughni al-Mubtaj, (Beirut: Dar al-Fikr, 1978), Jilid II, hlm. 323.

${ }^{33} \mathrm{Al}-\mathrm{B} a h u t i$, Kasysyaf al-Qina, Jilid III, hlm. 528.

${ }^{34}$ Al-Syarbaini al-Khatib, Mughni al-Mubtaj, Jilid II, hlm. 322. Al-Bahuti, Kasysyaf al-Qana, Jilid III, hlm. 
sesuai kesepakan, masing-masing dari mereka tidak dapat memutuskan hubungan secara sepihak setelah terjadinya kesepakatan"

\section{i. Al-Mugharasah}

Secara terminologi yang dikemukan para ahli fikih adalah:

$$
\text { أن يدقع الرجل أرضه لمن يغرس فيها شجر ا. }
$$

"Penyerahan tanah pertanian kepada seorang petani untuk ditanam"

Dari keseluruhan penjelasan tentang serikat usaha yang telah diutarakan di atas, maka mudharabah adalah serikat usaha antara pemilik modal dan pelaksana (pengelola), dalam menjalankan usaha tersebut pemilik modal sama sekali tidak terlibat secara langsung. Dewasa ini serikat usaha dalam bentuk mudharabah ini pada umumnya diberlakukan di bank-bank syari'at. Sementara serikat usaha dalam bentuk syirkah al-Inan adalah serikat usaha yang dilakukan oleh dua orang atau lebih. Apabila dilihat dari pengertian syirkah al-inan yaitu perserikatan modal, maka serikat usaha serta kegiatan yang dilakukan berdasarkan modal. serikat usaha dalam bentuk ini dapat ditemukan dalam sistem koperasi dan penanaman saham pada badanbadan usaha.

\section{ZAKAT SERIKAT USAHA DALAM KAJIAN EKONOMI ISLAM}

Dalam hukum Islam disebutkan bahwa esensi yang terkandung di dalam kerjasama adalah adanya ikatan kerjasama yang dilakukan oleh dua orang atau lebih dalam hal perdagangan atau yang lainnya. Dengan adanya kesepakan itu melahirkan kebolehan untuk bertindak hukum terhadap harta perserikatan itu dan berhak mendapatkan keuntungan sesuai dengan kesepakan yang telah disetujui.

Pada prinsipnya serikat yang dibolehkan berdasarkan syari'at Islam dalam melakukan kegiatan kerjasama suatu usaha, yang harus diperhatikan antara lain

${ }^{35}$ Ibnu 'Abidin, ibid, Jilid V, hlm. 203 
adalah: bebas dari unsur riba, keuntungan dan resiko ditanggung bersama, ada unsur kerjasama, transaksi harus yang halal. ${ }^{36}$

Adapun dalil-dalil dari al-Qur'an dan Hadis yang berkenaan dengan zakat hasil serikat usaha sebagai berikut :

1.al-Qur'an

Sehubungan dengan kewajiban zakat ini, Allah SWTberfirman dalam surah al-Taubah ayat 103 yang berbunyi :
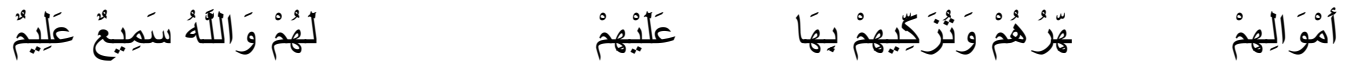

(103: )

"Ambillah zakat dari sebagian harta mereka, dengan zakat itu kamu membersihkan dan mensucikan mereka dan berdo'alah untuk mereka. Sesungguhnya do'a kamu itu (menjadi) ketentraman jiwa bagi mereka. Dan Allah SWTMaha Mendengar lagi Maha Mengetahui."

Pada prinsipnya semua harta yang berkembang dan diusahakan untuk mendapatkan tambahan adalah wajib zakat, hal ini berdasarkan firman Allah SWT dalam surat al-Baqarah ayat 267 yang berbunyi :

\section{(267: )

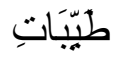 \\ يَاَأيُهْها الََذِينَ}

"Hai orang-orang yang beriman, nafkahkanlah di jalan Allah SWT sebagian dari hasil usahamu yang baik-baik dan sebagian dari apa yang kami keluarkan dari bumi untuk kamu...". 38

Pada ayat pertama dinyatakan dengan lafal (أموالهم), harta mereka. Kata mereka (ه) disini dapat berarti setiap orang secara individual dan dapat pula diartikan sebagai sekelompok orang. Meskipun para fukaha lebih berorientasi pada harta individu namun tidak menjadikan zakat tersebut harus dan wajib dikeluarkan hanya atas harta individu, sebab, terhadap harta kolektif, yaitu harta beberapa orang yang masih menyatu dalam bentuk harta waris dan harta syirkah usaha juga wajib dizakatkan.

Berkaitan dengan zakat hasil serikat usaha yang ditunjukkan oleh kata "kasabtum", maka hasil usaha yang dimaksud, seperti yang juga telah diuraikan di atas, dapat dikelompokkan pada dua bentuk, yaitu; usaha yang

${ }^{36}$ Yusuf al-Qardawi, Figh al-Zakah, (Mesir: Dar al-Fikr, 1997), hlm. 184. Lihat Juga Refky Fielnanda. (2018). Zakat Saham Dalam Sistem Ekonomi Islam (Kajian Atas Pemikiran Yusuf Qardhawi). Al-Tijary, 3(1), 57-67.

${ }^{37}$ Anonim, al-Qur'an dan Terjemahnya (Jakarta; Yayasan Penterjemah al-Qur'an, 1985), hlm. 297.

${ }^{38}$ Ibid, hlm. 310. 
bersifat harta benda (maliyah) dan usaha yang bersifat manfaat atau pengelolaan jasa. Pada ayat ini juga digunakan kalimat jama' "kasabtum", harta hasil usaha kalian. Kata kalian ( ) disini dapat berarti sejumlah individu dari kalian dan dapat pula diartikan beberapa individu yang bergabung di antara kalian. Oleh karenanya, sebagaimana pembahasan sebelumnya tentang kalimat 'mereka' (ه), dimensi dan orientasi dari kalimat 'kalian' ini juga mencakup harta hasil usaha bersama atau disebut juga dengan harta syirkah usaha.

2. Hadis Nabi Muhammad SAW

Adapun dalil dari Hadis Nabi Muhammad SAW adalah:

a. Hadis riwayat Abu Daud yang berbunyi :

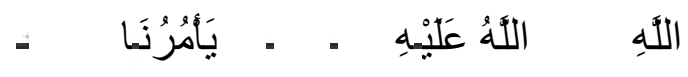

$$
{ }^{39}
$$

"Dari Samurah bin Jundub r.a berkata; Nabi SAW bersabda: telah memerintahkan kepada kami untuk mengeluarkan zakat dari barangbarang yang diperdagangkan".

Dalam Hadis Nabi Muhammad SAW di atas, disebutkan bahwa salah satu harta yang wajib dizakatkan adalah barang yang bersifat produktif, yaitu barang-barang yang dipersiapkan untuk aktifitas ekonomi, diperjual belikan. Setiap barang yang memiliki sifat seperti yang dijelaskan dalam Hadis tersebut, maka atasnya dikenakan zakat, baik harta perdagangan yang hanya dimiliki oleh perorangan maupun harta perdagangan milik serikat (beberapa orang).

b. Hadis riwayat Bukhari yang berbunyi :

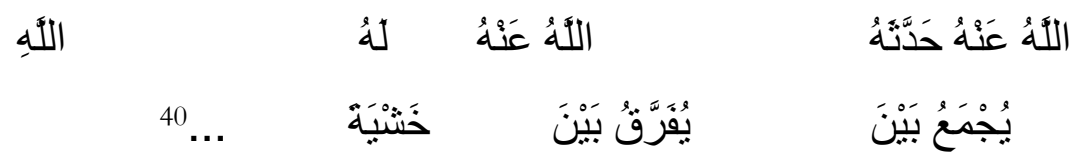

التَلُهُ عَلْيْهِ

"Dari Anas bin Malik bahwa Abubakar r.a menyuratinya tentang kewaiiban zakat, ...dan tidaklah seseorang menggabungkan yang terpisah dan tidak pula memisahkan antara sesuatu yang terkumpul, karena takut terhadap ketentuan zakat ... ".

\footnotetext{
${ }^{39}$ Mausu'ah al-Hadits al-Syarif, Sunan Abi Daud, Kitab: هيها هل , Bab: , hadits nomor 1335 .

لايجمع بين متفرق ولا يفرق بين مجتمع:Mausu'ah al-Hadits al-Syarif, Shahih al-Bukhari, Kitab: , Bab: hadits nomor 1358.
} 
c. Hadis riwayat Nasa'i yang berbunyi :

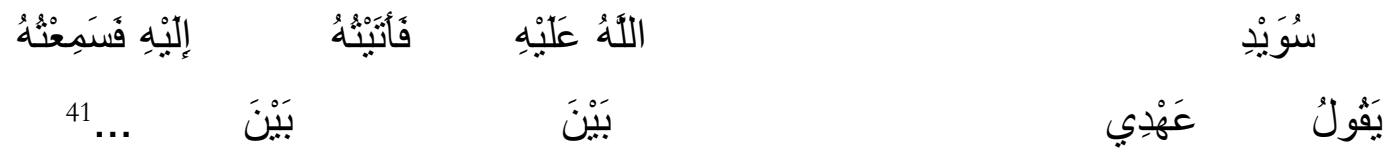

"Dari Suwaid bin Khaflah, dia berkata : Telah datang kepada kami seseorang yang hendak menyerahkan zakat kepada Rasulullah SAW, maka saya mendengar beliau bersabda: Sesungguhnya kami tidak akan memungut zakat dari anak hewan yang masih menyusui, tidak memisahkan ternak yang telah bercampur dan tidak pula mencampurkan yang terpisah...".

d. Hadis riwayat Bukhari yang berbunyi :

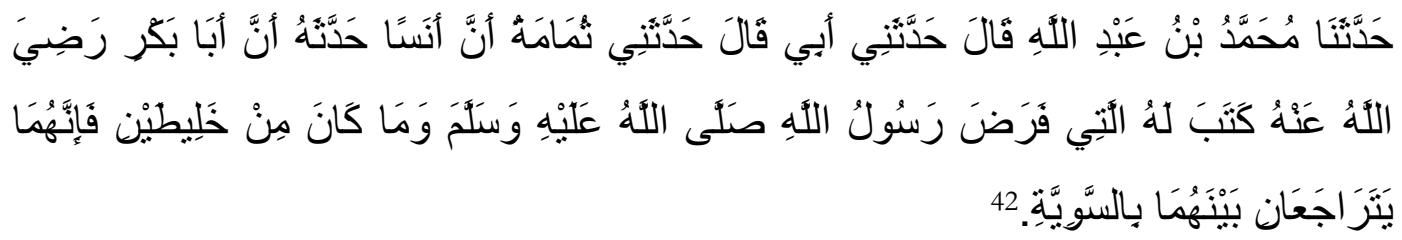

"Disampaikan dari Muhammad ibn Abdullah dari bapakku (Abdullah) dari Tsumamah dari Anas bahwa Abu Bakar ra. menyuratinya tentang yang diwajibkan oleh Rasulullah SAW, adapun harta dua orang yang bercampur menyatu maka harta tersebut dibagi dua dan dikembalikan kepada masing-masing mereka".

Berdasarkan ayat dan Hadis yang telah diuraikan di atas, para fuqaha melakukan intinbath hukum atasnya dan pada gilirannya terjadi kesamaan dan perbedaan pendapat di antara mereka, pendapat-pendapat yang berkembang berdasarkan kedua dalil tersebut antara lain:

1.Pendapat yang mengatakan bahwa penggabungan harta benda tidak mempengaruhi ketentuan zakat, yaitu Pendapat Imam Abu Hanifah, Malik bin Anas, Ahmad bin Hambal, Ibnu Hazm dan pengikutnya, sebagaimana yang dikemukakan oleh Ibnu Rusyd :

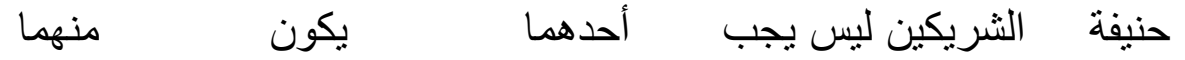

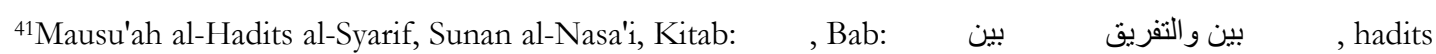
nomor 2414, lihat pula hadits nomor 2404 dan 2412. hadits senada juga ditemukan dalam Sunan Abu Daud, Kitab: , Bab: dan 18083.

, hadits nomor 1340 dan 1341, dan dalam Musnad Imam Ahmad, hadits nomor 68, 4405,

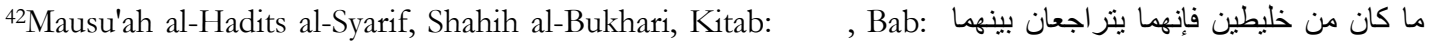
بالسوية, hadits nomor 1359.

${ }^{43}$ Ibnu Rusyd, Bidayah al-Mujtabid wa Nihayah al-Muqtasid, op cit, hlm. 188.
} 
"Maka sesungguhnya menurut Imam Malik dan Abu Hanifah bahwa dua orang yang berserikat tidak wajib zakat baginya, kecuali masing-masing mempunyai bagian nishab ".

Pendapat golongan ini berdasarkan pada :

$$
44 .
$$

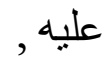

"Sesungguhnya yang sudah disepakati dasar yang tetap adalah zakat tidak diperhitungkan, kecuali atas milik orang perorangan ".

Dari pendapat yang telah dikemukakan di atas, dapat diambil pengertian tentang zakat harta benda perserikatan. Pada prinsipnya pendapat tersebut bahwa harta benda perserikatan wajib dizakatkan, apabila sudah mencapai satu nishab, hanya saja cara menghitung nishab zakatnya adalah pada setiap orang (individu) yang ikut berserikat, menghitung nisabnya menurut harta kekayaan yang tergabung dalam serikat, kemudian dihitung kekayaan yang dimiliki secara individu, lalu dihitung dan dikeluarkan zakatnya. Namun pada hakekatnya dalam hal ini yang dikenakan kewajiban mengeluarkan zakatnya adalah tetap pada individu secara pribadi, bukan atas nama perserikatan.

2.Pendapat yang mengatakan bahwa penggabungan harta benda mempengaruhi ketentuan zakat, yaitu Pendapat Imam Syafi'i, Ahmad bin Hambal dan pengikutnya berpendapat bahwa harta benda perserikatan dalam bentuk apapun, walaupun masing-masing pihak tidak mempunyai bagian sampai satu nishab, tetapi keseluruhan harta perserikatan itu sudah sampai satu nishab, maka harta itu wajib untuk dizakatkan, sebagaimana yang dijelaskan oleh Ibnu Rusyd berikut ini :

45.

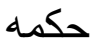

"Menurut Imam Syafi'i bahwa harta milik bersama hukumnya sama dengan harta milik satu orang ".

${ }^{44}$ Ibid,

${ }^{45}$ Ibnu Rusyd, Bidayah al-Mujtabid, ibid, hlm. 188. 
Pemahaman Imam Syafi'i terhadap Hadis yang diriwayatkan dari Anas di atas, bahwa orang-orang yang berserikat dalam keadaan apapun, janganlah memisahkan hartanya yang sudah dimasukkan ke dalam harta perserikatan dengan tujuan menghindar dari kewajiban zakat. Begitu pula orang-orang yang tidak berserikat, jangan pula menggabungkan hartanya dengan orang, supaya kewajiban zakatnya lebih kecil.

\section{KETENTUAN NISAB DAN KADAR WAJIB ZAKAT SERIKAT USAHA}

Apabila subjek zakat tersebut adalah pemilik harta dengan kriteria Islam, merdeka, baligh, berakal, dan memiliki nisab dengan milik yang sempurna, maka pemilik harta yang tidak memenuhi salah satu dari kriteria tersebut tidak diwajibkan mengeluarkan zakat, namun apabila subjek zakat adalah harta yang dimiliki, maka semua harta yang dimiliki oleh seseorang wajib dizakatkan, meskipun pemiliknya masih anak-anak, yatim, dan orang gila.

Dalam mengeluarkan zakat para fuqaha sepakat harus memenuhi ketentuan nisab dan haul. Nisab berarti ukuran atau jumlah tertentu dari harta yang terkena wajib zakat. Sedangkan haul ketentuan waktu kepemilikan selama satu tahun penuh. Nisab dan haul sebagaimana yang telah dijelaskan di atas sepenuhnya terfokus pada materi atau harta yang berada di tangan pemiliknya.

Adapun ketentuan nisab dan kadar wajib zakat serikat usaha disesuaikan dengan usaha yang dilakukan. Jika usaha tersebut dalam bentuk emas dan perak, maka nisabnya yaitu senilai 85 gram emas atau 600 gram perak. Sedangkan kadar zakatnya dua setengah persen $(2,5 \%$ atau $1 / 40)$ dan wajib adanya haul di akhir tahun. ${ }^{46}$

Jika serikat usaha tersebut dalam bentuk tanam-tanaman dan buah-buahan yang merupakan makanan sehari-hari, dari jenis buah-buahan ialah yang

461 dirham $=2,975$ gram perak $=200$ dirham $=595$ gram, 1 dinar $=4,25$ gram emas; 20 dinar $=85$ gram, Lihat: Yusuf al-Qardhawi, ibid., hlm. 260. Lihat Juga Muhammad al-Syaukani, ibid., hlm. 156 
dikeringkan dan anggur, dari jenis biji-bijian ialah berbagai macam jenis kacang, gandum, beras, maka nisabnya sebesar lima wasaq (652,8/653 $\mathrm{Kg})$ gandum. ${ }^{47}$ Sedangkan kadar kewajiban zakatnya adalah $10 \%$ apabila tanaman itu tergantung dengan siraman air hujan dan mata air, dan $5 \%$ jika memakai biaya pengairan dan beban-beban lainnya seperti irigasi, inteksida, pupuk dan lain-lain, maka kadar zakatnya sebagaimana di jelaskan dalam Hadis Nabi yang diriwayatkan oleh Ibnu Umar, dan tidak wajib adanya haul di akhir tahun. ${ }^{48}$

Jika serikat usaha tersebut dalam bentuk hewan ternak: kambing, sapi/kerbau, dan unta, maka nisabnya sebagaimana yang telah diuraikan sebelumnya tentang nisab kambing, sapi/kerbau, dan unta, dan wajib adanya baul di akhir tahun. Jika serikat usaha tersebut dalam bentuk harta rikaz (harta temuan) dan ma'din (harta galian), maka nisabnya seperlima bagian (20\%). Pendapat ini berdasarkan Hadis Nabi Muhammad SAW yang diriwayatkan dari Abi Hurairah yang mengatakan bahwa harta rikaz, harus dikeluarkan zakatnya seperlima bagian $(20 \%)$.

Jika serikat usaha tersebut dalam bentuk harta perdagangan, maka nisabnya yaitu senilai 85 gram emas atau 600 gram perak. Sedangkan kadar zakatnya dua setengah persen $(2,5 \%$ atau $1 / 40)$ dan wajib adanya haul di akhir tahun. ${ }^{49}$ Jika suatu serikat usaha bergerak secara simultan (multi usaha) dalam beberapa jenis usaha, maka zakat yang harus dikeluarkan sesuai dengan ketentuan masing-masing sub usaha tersebut. Sebuah serikat usaha yang secara simultan bergerak dalam bidang pengeboran minyak, konveksi, pertanian, dan perdagangan, maka zakat yang harus dikeluarkan darinya sesuai dengan persentase usaha yang dijalankan dan besarnya dana yang digunakan untuk masing-masing sub usaha secara proporsional.

${ }^{47}$ Sayyid Sabiq, ibid., hlm. 50.

${ }^{48}$ Muhammad al-Syaukani, ibid., hlm. 188.

${ }^{49}$ Lihat: Yusuf al-Qardhawi, ibid., hlm. 260. Lihat Juga Muhammad al-Syaukani, ibid., hlm. 156 


\section{PELAKSANAAN ZAKAT SERIKAT USAHA}

Dalam pelaksanaan zakat hasil serikat usaha, ditemukan dua versi pendapat ulama, yaitu antara mereka yang berpendapat bahwa penggabungan harta benda tidak mempengaruhi ketentuan zakat dan mereka yang berpendapat bahwa penggabungan tersebut mempengaruhi. Rincian dari perbedaan tersebut adalah sebagai berikut:

1. Pendapat kalangan ulama Hanafiyah, Malikiyah, Hanabilah, dan Ibnu Hazm bahwa:

Penggabungan harta benda tidak mempengaruhi ketentuan zakat, kecuali jika harta kekayaan masing-masing mencapai nisabnya secara individu dan zakat diperhitungkan atas milik orang perorangan, bukan atas milik bersama dalam serikat.

Menurut pendapat ulama di atas, bahwa jika harta kekayaan setiap orang yang tergabung dalam suatu serikat usaha mencapai nisabnya secara individu, maka ia dikenakan kewajiban untuk mengeluarkan zakatnya secara individu, bukan nisab secara keseluruhan harta serikat tersebut.

2. Pendapat kalangan ulama Syafi'iyah dan Hanabilah bahwa:

Harta benda perserikatan dalam bentuk apapun, walaupun masingmasing pihak tidak mempunyai bagian sampai satu nishab, tetapi secara keseluruhan harta perserikatan itu sudah sampai satu nishab, maka harta itu wajib untuk dizakatkan, dan zakatnya diperhitungkan atas milik bersama (atas nama suatu serikat), bukan atas milik orang perorangan dalam serikat, karena harta milik bersama dalam serikat usaha hukumnya sama dengan harta milik satu orang.

Setelah memperhatikan dan menganalisa kedua pendapat di atas, maka penulis melakukan perbandingan antara kedua pendapat tersebut, bahwa menurut versi Hanafiyah dalam pelaksanaan zakat harta serikat adalah harta 
milik seseorang yang berada dalam suatu serikat usaha dihitung secara individu oleh masing-masing anggota serikat, dengan ketentuan apabila sudah mencapai satu nisab dan memenuhi wajib zakat, maka masing-masing anggota tersebut diwajibkan mengeluarkan zakatnya secara individu dan cara menghitung nisabnya adalah pada setiap orang (individu) menurut harta kekayaan yang tergabung dalam serikat, lalu dikeluarkan zakatnya secara individu, bukan atas nama suatu serikat. Namun jika harta yang dimiliki oleh masing-masing anggota dalam serikat tersebut belum mencapai nisab, maka ia tidak diwajibkan mengeluarkan zakatnya. Sedangkan menurut versi Syafi'iyah dalam pelaksanaan zakat harta serikat adalah harta milik seseorang yang berada dalam suatu serikat usaha dihitung secara individu oleh masing-masing anggota serikat, dengan ketentuan apabila serikat usaha tersebut sudah mencapai satu nisab dan memenuhi wajib zakat, maka masing-masing anggota tersebut diwajibkan mengeluarkan zakatnya secara individu sesuai dengan jumlah saham (modal) yang dimiliki dalam serikat itu, dalam artian bukan atas nama suatu serikat.

Menurut analisa penulis dari dua versi tersebut di atas bahwa kewajiban untuk mengeluarkan zakat hanya dibebankan kepada setiap individu yang tergabung dalam serikat usaha, bukan atas serikat usaha itu sendiri. Jika harta kekayaan yang dimiliki oleh masing-masing individu dalam suatu serikat usaha dan secara serikat sudah mencapai satu nisab dan memenuhi ketentuan wajib zakat, maka ia dikenakan kewajiban untuk mengeluarkan zakatnya secara individu pula, namun jika harta kekayaan yang dimiliki oleh masing-masing individu belum mencapai satu nisab dan secara serikat sudah mencapai satu nisab, maka ia diwajibkan untuk menghitung harta kekayaannya yang berada dalam serikat usaha maupun harta yang dimiliki diluar serikat tersebut, jika setelah dihitung harta kekayaan itu sudah mencapai senisab, maka ia dikenakan kewajiban untuk mengeluarkannya, namun jika setelah dihitung harta kekayaan secara keseluruhannya itu juga belum mencapai senisab, maka ia tidak 
dikenakan kewajiban untuk mengeluarkan zakatnya. Dan pada hakikatnya seluruh harta kekayaan yang dimiliki oleh seseorang baik yang berada dalam serikat usaha maupun diluar serikat usaha jika sudah mencapai satu nisab dan memenuhi ketentuan wajib zakat, maka ia dikenakan kewajiban untuk mengeluarkan zakatnya.

\section{PENUTUP}

Kesimpulan utama penelitian ini ialah bahwa harta yang terdapat dalam serikat usaha wajib dikeluarkan zakatnya bila telah memenuhi ketentuan nisab dan haul dalam pelaksanaan zakat, zakat tersebut atas nama pemilik harta yang berserikat, bukan atas nama serikat usaha. Adapun kesimpulankesimpulan lain yang merupakan pendukung, pelengkap, dan rincian dari kesimpulan utama penelitian ini adalah:

1. Hukum zakat harta serikat usaha adalah wajib. Meskipun masih terdapat perbedaan pendapat para fuqaha dalam menentukan nisab dan haul zakat harta serikat usaha tersebut. Perbedaan ini didasarkan pada pemahaman mereka terhadap hukum zakat harta serikat usaha sebagaimana yang telah ditetapkan secara jelas dan tegas dalam al-Qur'an dan Sunnah.

2. Para fuqaha berbeda pendapat tentang ketentuan nisab zakat serikat usaha. Perbedaan tersebut adalah antara yang berpandangan bahwa nisab dan haul dilihat dari serikat usaha dan yang berpandangan bahwa perhitungan nisab atas harta masing-masing peserta serikat usaha, bukan pada serikat usaha.

3. Ketentuan kadar wajib zakat atas harta serikat usaha disesuaikan dengan jenis usaha yang dilakukan.

4. Pelaksanaan zakat serikat usaha disesuaikan dengan bidang usaha yang dilakukan oleh serikat usaha, menurut pandangan ulama Hanafiyah: nisab yang dihitung adalah nisab dari masing-masing individu peserta serikat usaha, bukan pada serikat usahanya sendiri, oleh karenanya dalam suatu serikat usaha boleh jadi salah seorang atau beberapa orang pesertanya tidak 
terkena wajib zakat karena tidak mencapai nisab secara individu. Menurut pandangan ulama Syafi'iyah: nisab yang dihitung adalah nisab pada serikat usaha, apabila serikat tersebut telah mencapai nisab maka atas masingmasing individu peserta serikat usaha dikenakan wajib zakat. 


\section{DAFTAR PUSTAKA}

Abu Abdullah, Malik Ibn Anas al-Ashbahi, Muwaththa’ al-Imam Malik, Mesir, Dar Ihya al-Turats al-Arabi, tt.

Ahmad, Mustaq, Etika Bisnis Dalam Islam, Terjemahan Samson Rahman, Jakarta, Pustaka Al-Kautsar, 2001.

Anonim, al-Qur'an dan Terjemahnya, Jakarta, Yayasan Penterjemah al-Qur'an, 1985.

Anonim, Kamus Besar Bahasa Indonesia, Jakarta, Balai Pustaka, 1990.

Antonio, Muhammad Syafi'i, Bank Syari'ah Wacana Ulama dan Cendikiawan, Jakarta, Bank Indonesia, 1999.

Baqiy, Muhammad Fuad Abdul, al-Mu'jam al-Mufahras li al-Fazh al-Hadis al-Nabawiy, Juz. II Matba'ah, Breil, Leiden, 1995.

Djalil, Ramlie, Peranan ZIS Dalam Pemberdayaan Ekonomi Umat, Makalah disampaikan pada Seminar Lokakarya Manajemen BAZIS tanggal 11 Agustus 1998, Jambi: BAPPEDA Tingkat I, 1998.

Fielnanda, Refky. "Zakat Saham Dalam Sistem Ekonomi Islam (Kajian Atas Pemikiran Yusuf Qardhawi)." Al-Tijary 3.1 (2018): 57-67.

Hazm, Abi Muhammad 'Aliy bin Ahmad bin Sa'id bin, al-Muhalla, Dar al-Fikr, t.tp., t.th.,

Ibnu Hajar al-Asqalani, Fath al-Bari Syarah Shahih al-Bukhari, Beirut: Dar al-Fikr, 1991, Jilid IV.

Ibnu Daqiqi al-Id, Ihkam al-Ahkam Syarah Umdah al-Ahkam, Beirut: Dar al-Kutub alIlmiyah, tt, Jilid I.

Ibn Manzur, Abi al-Fadhl Jamaluddin ibn Makram, Lisan al-Arab, Bairut, Dar alShadir, li al-Thiba'ah wa al-Nasyr, t.th., Jld. XI.

Ibnu 'Abidin, Radd al-Mukhtar Ala al-Durr al-Mukhtar, Beirut, Dar al-Fikr, tt, juz V.

Ibnu Rusyd, Muhammad bin Ahmad al-Qurtubi, Bidayah al-Mujtabid wa Nihayah alMuqtasid, , Mesir, Musthafa al-Baby al-Halaby, 1370 H / 1950 M. 
Khatib, Muhammad al-Syarbaini, al-, Mughni al-Mubtaj, Beirut, Dar al-Fikr, 1978, juz II.

Mausu'ah al-Hadis al-Syarif, Edisi II, tahun 2000 (1991-1997), Syirkah al-Baramij alIslamiyyah al-'Alamiyyah, sistem penomoran internasional.

Muhammad Syah, Ismail, Filsafat Hukum Islam, Jakarta: Bumi Aksara, 1992.

Muhammad ibn Idris al-Syafi'i, al-Umm, Beirut: Dar al-Fikr, 1983/1393, Juz II.

M. Syukri Ghazali, dkk, Pedoman Zakat, Jakarta: Proyek Pembinaan Zakat dan Wakaf, 1991.

Qadir, Abdurrahman, Zakat (Dalam Dimensi Mahdhah dan Sosial), Jakarta, Raja Grafindo Persada, 2001, Cet II.

Qardhawi, Yusuf, Al-. Fiqh al-Zakah, Beirut, Muassasah al-Risalah, 1994, Juz I.

Qosim bin Salam, Abi Ubaid, Kitab al-Amwal, Kairo, Dar al-Fikq, 1975.

Sabiq, Sayyid, Fiqh al-Sunnah, Beirut, Dar al-Fikr, 1983, cet. II, juz I, III.

Saefuddin, Ahmad Muflih, Pengelolaan Zakat Ditinjau dari Aspek Ekonomi, Bontang, Badan Dakwah Islamiyah LNG, 1986.

Syafi'i, Muhammad Ibn Idris, Abu Abdullah, al-, al-Umm, Beirut, Dar al-Ma'rifah, 1393 , cet. II, juz : II.

Syalabi, Ahmad, Tarekh al-Tasyri al-Islami, Kairo, Maktabah al-Nahdhah alMisriyah, t.t., juz I.

Syirazi, Ibrahim Ibn Ali, al-, al-Muhadzdzab fi al-Figh al-Imam al-Syafi'i, Beirut, Dar al-Fikr, tt., Juz I.

Zaidan, Abdul Karim, al-Wajiz fi Ushul al-Fiqh, Mesir, Dar al-Tauzi' wa al-Nasyr alIslamiyah, 1993, juz I.

Zuhaili, Wahbah, Al-. Fiqh al-Islami wa Adillatubu, Damsyik, Dar al-Fikr, 1989, Cet. III, Juz II. 